\title{
Seal Glass for Solid Oxide Fuel Cells
}

\author{
Montri Suklueng
}

Additional information is available at the end of the chapter

http://dx.doi.org/10.5772/intechopen.74180

\begin{abstract}
Barium calcium aluminum boro-silicate glass (BCABS) is used as a sealant for Solid Oxide Fuel Cells (SOFCs) to protect against air and hydrogen gas leaking at $800^{\circ} \mathrm{C}$. One major problem is the chemical reaction of this glass with barium oxide and other materials in the composition such as Ba-Y-Co-Fe (BYCF) and Ba-Sr-Co-Fe (cathode) used in the fuel cell components, leading to the formation and spreading of barium aluminosilicate glass on the cathode surface in the fuel cell. This investigation indicated that adding $0.4 \mathrm{~mol} \% \mathrm{ZrO}_{2}$ to BCABS prevents the formation of barium aluminosilicate glass. Generally, the sealing glass of fuel cells must show high resistivity for no disturbance to electricity from the fuel cell system when generating the electron. The $0.4 \mathrm{~mol} \% \mathrm{ZrO}_{2}$ to $\mathrm{BCABS}$ is generated with resistivity of $4 \mathrm{M} \Omega$ that is useful for SOFCs technology. The thermal expansion coefficient (TEC) in SOFCs is the major condition for producing the cell layers. The thermal expansion coefficient of SOFCs based on each layer (cathode, electrolyte, anode, interconnect and sealant) should be closed to prevent broken cells. The thermal expansion coefficient is $12.40 \times 10^{-6} /{ }^{\circ} \mathrm{C}$ matched with the TEC of the $\mathrm{GDC}_{10}$ electrolyte. Therefore, BCABS glass with $0.4 \mathrm{~mol} \% \mathrm{ZrO}_{2}$ generated a novel composite for SOFCs.
\end{abstract}

Keywords: BCABS sealing glass, SOFCs, electrical stability, thermal expansion coefficient

\section{Introduction}

Solid oxide fuel cells (SOFCs) are a type of power source conversion device which can transform hydrogen or hydrocarbon gas in fuel into electricity at an intermediate temperature of $600-800^{\circ} \mathrm{C}$. SOFCs consist of three layers (cathode/electrolyte/anode) that are designed with a tubular and planer shape [1]. The fuels are often pumped to flow into the SOFC system but it is possible that leaks can occur when using this system. Therefore, excellent sealing is essential to prevent external leaks as well as to contain fuels inside the SOFCs. The sealing composition must provide hermeticity, electronic insulation, and a similar thermal expansion coefficient 
(TEC) to match with the SOFC system [2]. Thermal stability is necessary and the operating system should be able to work for long periods in harsh conditions. Furthermore, the sealant must be able to survive the thermal cycles for $40,000 \mathrm{~h}$ at intermediate temperatures of 500 $800^{\circ} \mathrm{C}$ [3]. The character of the seal glass should enhance stability and durability in both chemical and mechanical forms [2].

Based on the glass ceramic sealant type, the best is BCABS with the following composition: $(\mathrm{mol} \%) 35 \mathrm{BaO}, 15 \mathrm{CaO}, 5 \mathrm{Al}_{2} \mathrm{O}_{3}, 37 \mathrm{SiO}_{2}, 8 \mathrm{~B}_{2} \mathrm{O}_{3}$ [4]. This sealant is derived through the chemical reaction with barium compositions on the cathode side of the SOFCs systems; for example, BSCF (Ba-Sr-Co-Fe) [5], or BYCF (Ba-Y-Co-Fe) [6] that leads to the formation of barium aluminosilicate $[7,8]$ on the surface as shown in Figure 1. But how can we stop the barium aluminosilicate which blocks the electricity generation of SOFCs? $\mathrm{ZrO}_{2}$ reveals better thermal shock resistance at $400^{\circ} \mathrm{C}$, and improves thermal oxidation resistance [10, 11]. BCABS with added $(0.4 \mathrm{~mol} \%) \mathrm{ZrO}_{2}$ (BCABS- $0.4 \mathrm{~mol} \% \mathrm{ZrO}_{2}$ ) is shown to be an excellent glass ceramic sealant for operating SOFCs that can also match the required TEC, has high resistivity, and no cracks. The TEC of BCABS-0.4 mol\% $\mathrm{ZrO}_{2}$ of $12.17-12.78 \times 10^{-6} /{ }^{\circ} \mathrm{C}$ also matches with the $\mathrm{GDC}_{10}$ electrolyte at $13.08 \times 10^{-6} /{ }^{\circ} \mathrm{C}$. BCABS- $0.4 \mathrm{~mol} \% \mathrm{ZrO}_{2}$ showed resistivity of $4 \mathrm{M} \Omega \mathrm{cm}$ for $100 \mathrm{~h}$. BCABS- $0.4 \mathrm{~mol} \% \mathrm{ZrO}_{2}$ of SEM also exhibited a smooth surface free of cracks, blisters and without barium aluminosilicate [9]. The melting point is $867.25^{\circ} \mathrm{C}$ [9].

Due to the SOFCs being developed for use at low operating temperatures, this will make the SOFC system highly efficient. Therefore, the development of glass ceramic sealants containing the addition of $0.4 \mathrm{~mol} \% \mathrm{ZrO}_{2}$ in the BCABS glass composition can be shown to use low cost advanced materials for SOFC technology. This sealing glass can prevent the spread of barium aluminosilicate on the surface of the barium composition on the cathode side of the SOFC system. The melting point of the composition is $867.25^{\circ} \mathrm{C}$. The electrical resistivity of this mixture is $4 \mathrm{M} \Omega \mathrm{cm}$ which is 8 times lower than the original BCABS. The TEC is matched with SOFCs based on the $\mathrm{GDC}_{10}$ electrolyte that is valued at around $12.17-12.78 \times 10^{-6} /{ }^{\circ} \mathrm{C}[12]$. The microstructure between cathode and glass is free of cracks and shows good adherence to both surfaces. These properties of BCABS- $0.4 \mathrm{ZrO}_{2}$ composition can be promoted as a sealant for SOFC low cost technology which has barium oxide content.

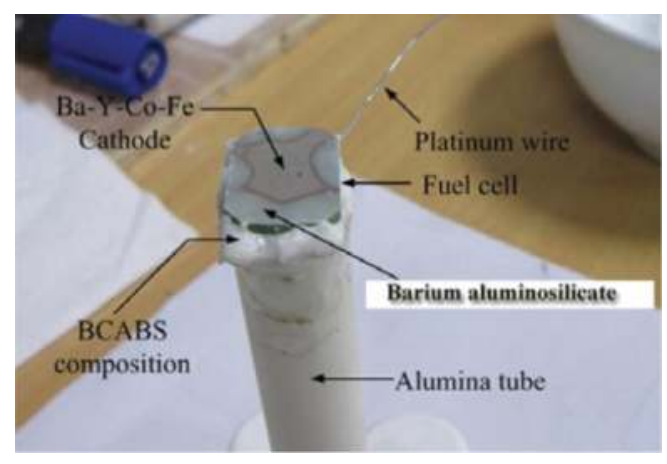

Figure 1. The sealing glass BCABS was sintered at $800^{\circ} \mathrm{C}$ for $5 \mathrm{~h}$ and the barium aluminosilicate coated on the solid oxide fuel cell surface [9]. 


\section{Preparation of materials}

The materials for this glass sealant show novel composition with added $\mathrm{ZrO}_{2}$ in $\mathrm{BCABS}$ under a $\mathrm{mol} \%$ ratio as exhibited in Table 1. Commercial powders $\mathrm{BaO}(99 \%), \mathrm{CaO}(99 \%), \mathrm{Al}_{2} \mathrm{O}_{3}(99 \%)$, $\mathrm{B}_{2} \mathrm{O}_{3}(99 \%), \mathrm{SiO}_{2}(99 \%)$ and $\mathrm{ZrO}_{2}(99 \%)$ were obtained from Sigma Aldrich $\mathrm{GmbH}$, Germany. Stoichiometric amounts of powder were mixed together to get the glass sealant composite. The powder mixtures were ground for $1 \mathrm{~h}$ and mixed with distilled water, generating the high temperature. Thus, for the best safety of preparation, the mixtures were prepared using a stainless steel tray or thermal ceramic tray. It is important not to touch the composition when the distilled water is first mixed with powder because of the high thermal production and dust! The mixture was milled with cylindrical alumina balls using a horizontal rotary ball mill for $24 \mathrm{~h}$ and then dried in the oven at $150^{\circ} \mathrm{C}$ until it became a powder as shown Figure 1. The powders were ground again for $4 \mathrm{~h}$ in our in-house designed grinding machine and sieved at 150 mesh size, resulting in the fine powder of sealing glass for SOFC technology. The calcinated batch was melted under air ambience in a solid oxide fuel cell system (cathodelelectrolytelanode), with a platinum wire and alumina tube at $1000^{\circ} \mathrm{C}$. The melting was then quenched between an alumina tube and fuel cell to obtain the glass frit to be used for electrical stability as shown in Figure 2.

\begin{tabular}{lllll}
\hline Composition & \multicolumn{2}{l}{ Samples } & & \\
\cline { 2 - 5 } & BCABS & BCABS-1ZrO & BCABS-2ZrO $_{2}$ & BCABS-3ZrO $_{2}$ \\
\hline $\mathrm{BaO}$ & 35 & 35 & 35 & 35 \\
$\mathrm{CaO}$ & 15 & 15 & 15 & 15 \\
$\mathrm{Al}_{2} \mathrm{O}$ & 5 & 5 & 5 & 5 \\
$\mathrm{SiO}_{2}$ & 37 & 36.6 & 36.2 & 35.9 \\
$\mathrm{~B}_{2} \mathrm{O}_{3}$ & 8 & 8 & 8 & 8 \\
$\mathrm{ZrO}_{2}$ & 0 & 0.4 & 0.8 & 1.1 \\
\hline
\end{tabular}

Table 1. Chemical composition of the of the sealing glass (mol\%) [9].

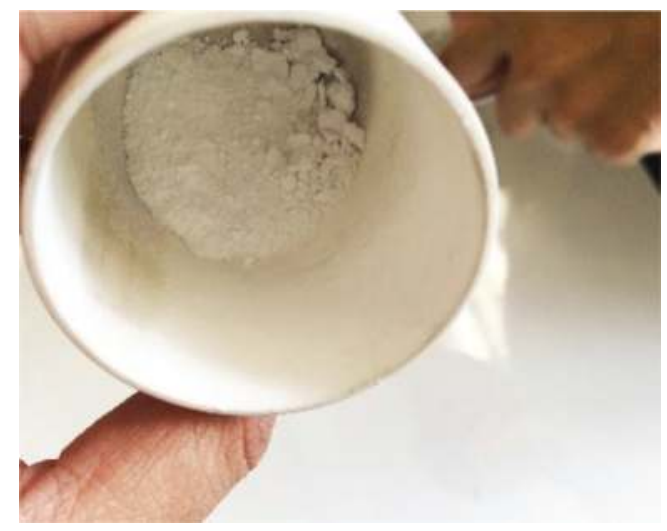

Figure 2. The BCABS- $1 \mathrm{ZrO}_{2}$ was prepared after drying in the over at $150^{\circ} \mathrm{C}$ for $4 \mathrm{~h}$. 
However, the preparation of the glass sealant must be practiced because it involves rheology and sintering. Therefore, before using this glass sealant in the real experiments, it is necessary to learn how to control the glass flow at the high temperature for the sealant. For example in SOFCs technique, increasing for $90 \mathrm{~min}$ to $1000^{\circ} \mathrm{C}$ and then stabilizing for $1 \mathrm{~min}$, before then cooling down for $90 \mathrm{~min}$ to room temperature.

\section{Physical properties}

The chemical reactions of the sealing glass BCABS, BCABS doped with $\mathrm{ZrO}_{2}$, and the solid oxide fuel cells after they were sintered at $1000^{\circ} \mathrm{C}$ for $1 \mathrm{~h}$ are shown in Figure 3(a)-(d). The compositions related appear in Table 1. The BCABS composition revealed an excellent connection between the fuel cell and glass; some chemical reactions on the fuel cell due to the barium aluminosilicate are spread on the fuel cell [13], Figure 4(a). BCABS- $1 \mathrm{ZrO}_{2}$ glass showed no reaction in the fuel cell with a shiny, high adhesive glass composition deposited on the fuel cell surface in Figure 4(b). BCABS doped $0.4 \mathrm{~mol} \%$ may affect the chemical glass composition and can be obviously revealed without barium aluminosilicate coated on the fuel cell. The reasons

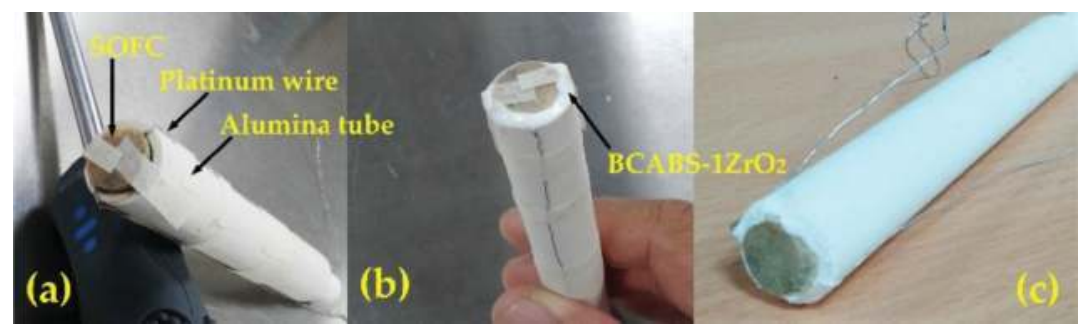

Figure 3. (a) The preparation for measuring power density of the SOFC based on the pellet comprising the SOFC pellet, alumina tube and platinum wire; (b) BCABS- $1 \mathrm{ZrO}_{2}$ glass quenched between the SOFC pellet and alumina tube; (c) BCABS- $1 \mathrm{ZrO}_{2}$ glass after sintering at $1000^{\circ} \mathrm{C}$ for $1 \mathrm{~min}$.
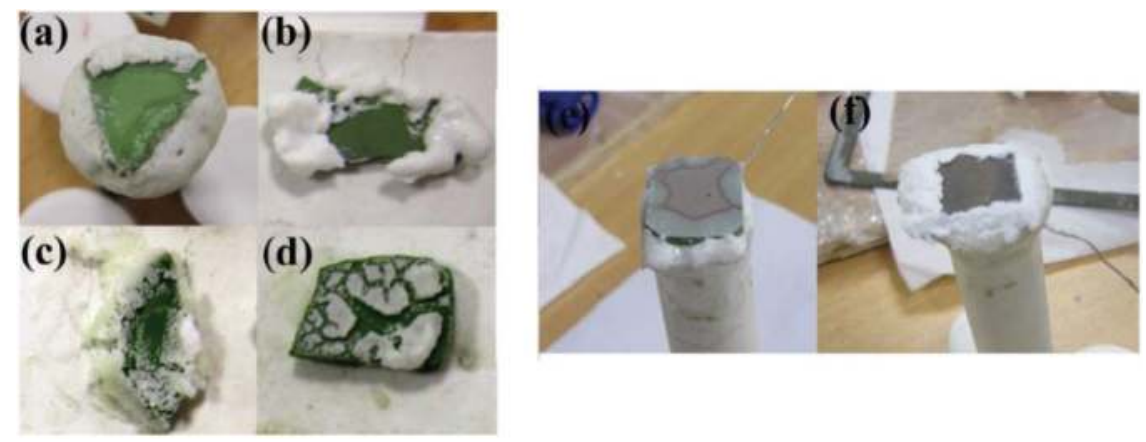

Figure 4. Comparison of the chemical reaction between glass ceramic sealant and solid oxide fuel cell: (a) BCABS, (b) $\mathrm{BCABS}-1 \mathrm{ZrO}{ }_{2}$, (c) $\mathrm{BCABS}-2 \mathrm{ZrO}_{2}$, and (d) $\mathrm{BCABS}-3 \mathrm{ZrO}_{2}$. Picture exhibits the comparison of glass ceramic sealants: (e) BCABS and (f) $\mathrm{BCABS}-1 \mathrm{ZrO}_{2}$ [9]. 
for the chemical compound with crystallographic structure are explained in the XRD analysis section. The glass $\mathrm{BCABS}-2 \mathrm{ZrO} \mathrm{O}_{2}$ and $\mathrm{BCABS}-3 \mathrm{ZrO} \mathrm{r}_{2}$ showed clear cracks on the fuel cell that may be attributed to the high quantity of $\mathrm{ZrO}_{2}$ generating the pin holes and pores in the surface $[14,15]$. Therefore, the sealing glass $\mathrm{BCABS}-1 \mathrm{ZrO}_{2}$ is an excellent sealing material for the investigation of properties leading to no reaction on the fuel cell surface. BCABS and BCABS- $1 \mathrm{ZrO}_{2}$ sealing glass were sintered with fuel cells that clearly compared the different sealing glasses as shown in Figure 4(e) and (f).

\section{Differential thermal analysis (DTA)}

The chemical reaction of the glass sealant at high temperatures is very important for application to SOFCs technology for the analysis phase of chemical reactions and melting points that can be designed by time and temperature for coating between the alumina tube and fuel cell. Differential thermal analysis (DTA) is the one instrument for measuring which is based on the peak represented chemical reaction and melting point. DTA plots of the investigated BCABS$1 \mathrm{ZrO}_{2}$ glass are shown in Figure 5. An endothermic baseline shift indicates glass transition and an exothermic shift indicates crystallization. The plots show the inflection in the temperature range from room temperature to $1000^{\circ} \mathrm{C}$ with an intense exothermic peak at $76.82^{\circ} \mathrm{C}(\mathrm{Tp})$. This range, from 40 to $150^{\circ} \mathrm{C}$ is associated with the elimination of adsorbed and zeolitic $\mathrm{H}_{2} \mathrm{O}$. The coordinated $\mathrm{H}_{2} \mathrm{O}$ is removed in this heating range. The glass transition temperature $\mathrm{T}_{\mathrm{g}}$ exhibits the estimates to be $196.87,306.13,427.02$ and $867.25^{\circ} \mathrm{C}$ from this point of intersection of the tangents drawn at the slope change. The peak of $\mathrm{T}_{\mathrm{g}}$ at $427.02^{\circ} \mathrm{C}$ corresponded to the thermal

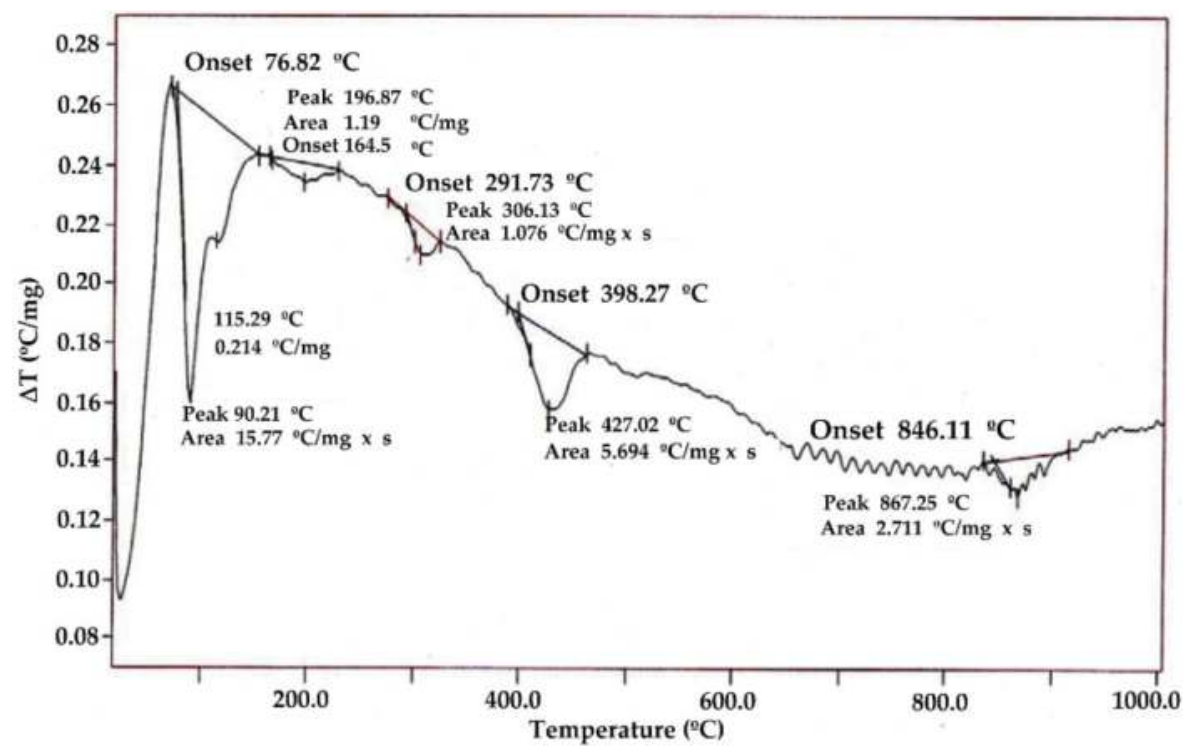

Figure 5. Differential thermal analysis (DTA) curve of investigated $\mathrm{BCABS}-1 \mathrm{ZrO}_{2}$ glass [9]. 
expansion curve of $\mathrm{BCABS}-1 \mathrm{ZrO}_{2}$. The glass transition $\mathrm{T}_{\mathrm{g}}$ of $867.25^{\circ} \mathrm{C}$ is the melting point. However, the glass sealant should be sintered over the melting point for coating the gap between the SOFC and alumina tube without leaks. For example, a temperature at $1000^{\circ} \mathrm{C}$ for 1 min can reveal the beautiful coating as shown in Figure 3(c).

\section{X-ray diffraction (XRD) analysis}

X-ray diffraction (XRD) is a versatile, non-destructive, analytical technique that reveals detailed information involving the chemical composition, crystallographic structure and physical properties of materials [16]. In the case of powder diffraction, this technique is used to characterize the crystallographic structure, crystallite size and preferred orientation in polycrystalline or powdered solid samples [17]. Powder diffraction is also commonly used to identify unknown substances by comparing the diffraction data against a database matched by the International Centre for Diffraction Data (ICDD). Based on the BCABS- $1 \mathrm{ZrO}_{2}$ glass, XRD indicates the inclusion of many compositions such as Barium Calcium Silicate $\left(\mathrm{Ca}_{0.1} \mathrm{Ba}_{0.9} \mathrm{SiO}_{3}\right)$, Barium Aluminum Silicate $\left(\mathrm{BaAl}_{2} \mathrm{Si}_{2} \mathrm{O}_{8}\right)$, Silicon Oxide $\left(\mathrm{SiO}_{2}\right)$, Silicon ( $\left.\mathrm{Si}\right)$, Calcium Aluminum Silicate Hydroxide $\left(\mathrm{Al}_{2} \mathrm{Ca}_{2} \mathrm{O}_{13} \mathrm{Si}_{3}\right)$, Barium Zirconium Silicate $\left(\mathrm{Ba}_{2} \mathrm{Zr}_{2} \mathrm{Si}_{3} \mathrm{O}_{12}\right)$ and Calcium Silicate $\left(\mathrm{CaSiO}_{3}\right)$. The major peak is $\mathrm{Ca}_{0.1} \mathrm{Ba}_{0.9} \mathrm{SiO}_{3}$ leading to $\mathrm{BaO}, \mathrm{CaO}$ and $\mathrm{SiO}_{2}$ that are the main components. Additionally, Barium Zirconium Silicate $\left(\mathrm{Ba}_{2} \mathrm{Zr}_{2} \mathrm{Si}_{3} \mathrm{O}_{12}\right)$ is very interesting because this compound combined with the Barium Oxide and Zirconium Oxide may stop the Barium Aluminosilicate coating on fuel cell surfaces. This composition may cause decreased resistivity such that the resistance of $\mathrm{BCABS}-1 \mathrm{ZrO}_{2}$ is generated 8 times lower than BCABS (Figure 6).
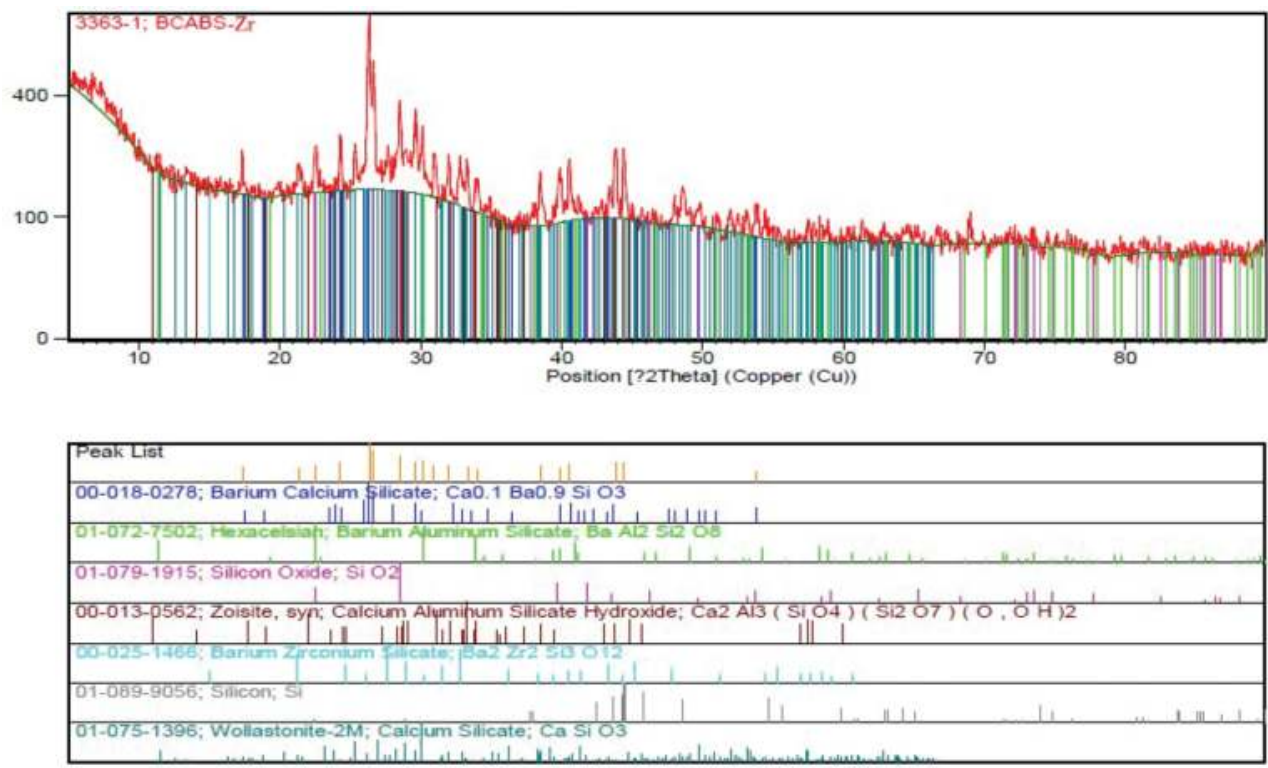

Figure 6. XRD data of the $\mathrm{BCABS}-1 \mathrm{ZrO}_{2}$ after sintering at $1000^{\circ} \mathrm{C}$ for $1 \mathrm{~min}$. 


\section{Thermal expansion}

Based on SOFCs technology are contained the cathode, electrolyte and anode layer. All of the three layers must be controlled by the thermal expansion coefficient the same as the electrolyte, while this experiment uses the $\mathrm{GDC}_{10}$ electrolyte. Hence, the thermal expansion coefficients (TEC) of the cathode and anode should be close to that of the electrolyte [18]. Because SOFCs are operated at high temperatures of $600-800^{\circ} \mathrm{C}$, all the layers are expanded. In cases where the three layers of SOFCs have different thermal expansion coefficients they can easily be broken. For this reason, the thermal expansion coefficient of sealing glass must also be close to that of the $\mathrm{GDC}_{10}$ electrolyte. The linear thermal expansion of BCABS and BCABS- $1 \mathrm{ZrO}_{2}$ glass is shown in Table 2. Thermal expansion of BCABS exhibited linear expansion, with a thermal expansion coefficient of $12.40 \times 10^{-6} /{ }^{\circ} \mathrm{C}$. The $\mathrm{BCABS}-1 \mathrm{ZrO}_{2}$ also showed linear thermal expansion between 34 and $400^{\circ} \mathrm{C}$, with a thermal expansion coefficient of $12.78 \times 10^{-6} /{ }^{\circ} \mathrm{C}$. The increase in TEC from 34 to $600^{\circ} \mathrm{C}$ is shown in Table 2. Thermal expansion of BCABS- $1 \mathrm{ZrO}_{2}$ also matches with the $\mathrm{GDC}_{10}$ electrolyte at $13.08 \times 10^{-6} /{ }^{\circ} \mathrm{C}[19]$.

\begin{tabular}{|c|c|c|c|c|}
\hline \multirow[t]{2}{*}{ Compositions } & \multicolumn{4}{|c|}{ Thermal expansion coefficient $\left(\times 10^{-6} /{ }^{\circ} \mathrm{C}\right)$} \\
\hline & $34-200\left({ }^{\circ} \mathrm{C}\right)$ & $34-400\left({ }^{\circ} \mathrm{C}\right)$ & $34-600\left({ }^{\circ} \mathrm{C}\right)$ & $34-800\left({ }^{\circ} \mathrm{C}\right)$ \\
\hline BCABS-1ZrO ${ }_{2}$ & 12.17 & 12.78 & 16.53 & 11.70 \\
\hline BCABS & 12.20 & 12.81 & 12.54 & 12.40 \\
\hline
\end{tabular}

Table 2. Comparison of thermal expansion coefficient properties of sealing glass $\mathrm{BCABS}_{\mathrm{ZrO}} \mathrm{Z}_{2}$ and $\mathrm{BCABS}$ [9].

\section{Electrical stability analysis}

Sealing glass in SOFCs operation is a part which should be an effective electrical insulator to support the fuel cell in highly efficient generation of electricity. However, based on the real experiment, the SOFC technology needs to be interconnected to pass the electricity to the external circuit from the high temperature system. For the purpose of full option of this experiment, $\mathrm{La}_{0.08} \mathrm{Sr}_{0.20} \mathrm{Cr}_{0.92} \mathrm{Co}_{0.08} \mathrm{O}_{3}$ was used for the fuel cell interconnect. Investigation by Acchar et al. has shown that this interconnect has the best composition of materials to achieve the ideal features of an interconnect; for example high density, porosity, and high conductivity [20].

Electrical stability analysis was measured with the interconnect $\mathrm{La}_{0.08} \mathrm{Sr}_{0.20} \mathrm{Cr}_{0.92} \mathrm{Co}_{0.08} \mathrm{O}_{3}$. Glass was exposed to ambient air on one side and $\mathrm{H}_{2}, 2.7 \% \mathrm{H}_{2} / \mathrm{Ar}$ saturated with 20 or $30 \mathrm{vol} \% \mathrm{H}_{2} \mathrm{O}$ on the other side. A graphic diagram of the test set-up, detailing the perimeter seal, gas chamber and electrical connection is shown in Figure 7. The electrical stability of both glasses $\mathrm{BCABS}$ and $\mathrm{BCABS}-1 \mathrm{ZrO}_{2}$ was investigated in the furnace at a temperature of $800^{\circ} \mathrm{C}$ for $100 \mathrm{~h}$. Some of the samples were intentionally broken for interfacial characterization of cross-sections using a scanning electron microscope (SEM). Figure 8 exhibits the electrical conductivity of the interconnect $\left(\mathrm{La}_{0.08} \mathrm{Sr}_{0.20} \mathrm{Cr}_{0.92} \mathrm{Co}_{0.08} \mathrm{O}_{3}\right)$ composite at different temperatures. Using the electrical circuit connection seen in Figure 7, the resistance between BCABS- $1 \mathrm{ZrO}_{2}$ and the interconnect $\left(\mathrm{La}_{0.08} \mathrm{Sr}_{0.20} \mathrm{Cr}_{0.92} \mathrm{Co}_{0.08} \mathrm{O}_{3}\right)$ composite was measured. 
Electrical equivalent circuit
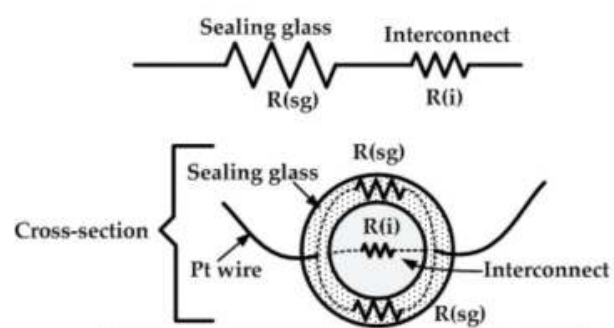
Digital Multimeter VA18B USB interface

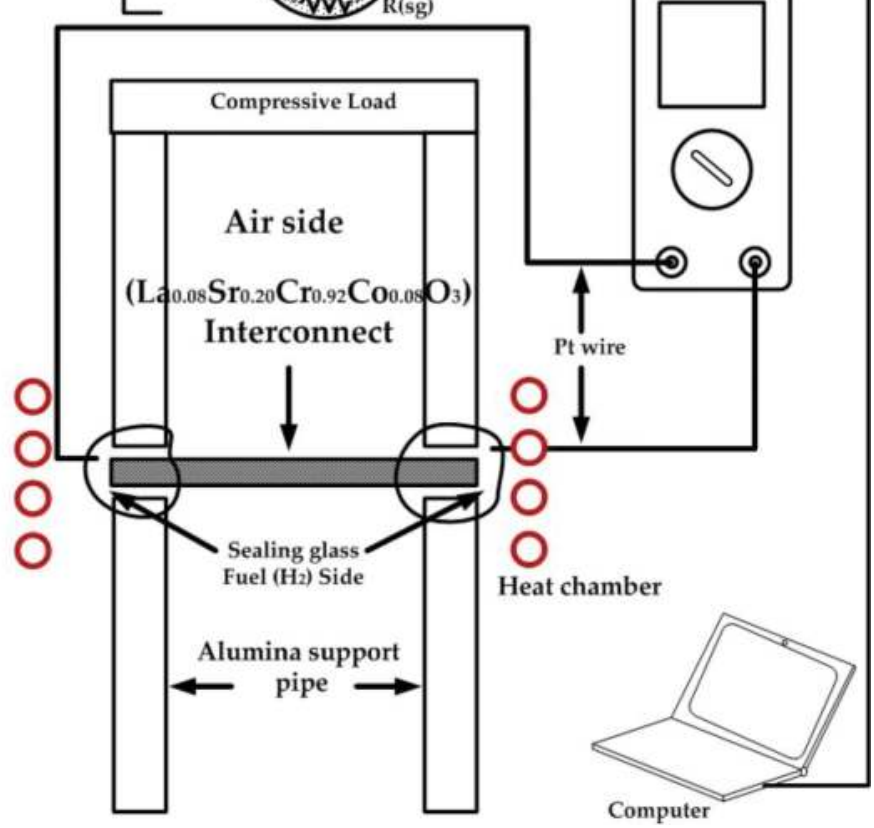

Figure 7. The graphic diagram exhibits the set-up of electrical stability measurement, the glass covered the interconnect and connected with platinum $(\mathrm{Pt})$ wire used for measuring resistivity [9].

However, the interconnect $\left(\mathrm{La}_{0.08} \mathrm{Sr}_{0.20} \mathrm{Cr}_{0.92} \mathrm{Co}_{0.08} \mathrm{O}_{3}\right)$ composite has very low resistivity. Therefore, the major resistivity of $\mathrm{BCABS}-1 \mathrm{ZrO}_{2}$ was measured, as indicated in Figure $\mathbf{9}(\mathbf{a}, \mathbf{b})$ [9]. The measurement of the resistivity of sealing glass and interconnect materials can be written in the form of electrical equivalent circuit. The resistance is $\left(\mathrm{La}_{0.08} \mathrm{Sr}_{0.20} \mathrm{Cr}_{0.92} \mathrm{Co}_{0.08} \mathrm{O}_{3}\right)$ interconnect (Ri) and $\mathrm{BCABS}-1 \mathrm{ZrO} 2$ sealing glass (Rsg), while the cross-section is fitted by electrical circuit as shown in Figure 7 and this cross-section also corresponds to Figure 3(b). All resistances are connected in series circuits as represented in Eq. (1). However, the resistance of $\left(\mathrm{La}_{0.08} \mathrm{Sr}_{0.20} \mathrm{Cr}_{0.92} \mathrm{Co}_{0.08} \mathrm{O}_{3}\right)$ interconnect (Ri) is very low, which must easily release electrons to the external circuit in a real experiment of SOFCs. Therefore, the total resistance from this investigation is $\mathrm{BCABS}-1 \mathrm{ZrO}_{2}$ sealing glass (Rsg).

$$
\mathrm{R}_{\text {total_Realing glass }}=\mathrm{R}(\mathrm{rg})+\mathrm{R}(\mathrm{i})
$$


The electrical stability was investigated for BCABS and BCABS- $1 \mathrm{ZrO}_{2}$ for $100 \mathrm{~h}$ at $800^{\circ} \mathrm{C}$, as shown in Figure $\mathbf{9}(\mathbf{b})$. The resistance of BCABS is 8 times higher than $\mathrm{BCABS}-1 \mathrm{ZrO} \mathrm{C}_{2}$. The trends indicated a gentle step down at $48 \mathrm{~h}$ with both stabilized until $100 \mathrm{~h}$. The $0.4 \mathrm{~mol} \%$ $\mathrm{ZrO}_{2}$ doped in BCABS revealed decreasing electrical resistivity of the sealing glass. The electrical stability of BCABS and $\mathrm{BCABS}-1 \mathrm{ZrO}_{2}$ sealing glass at different temperatures is shown in Figure 9 [9]. Both compositions exhibited decreasing resistivity at $520^{\circ} \mathrm{C}$. The composition might change phase at $520^{\circ} \mathrm{C}$ since that is one of the major properties of BCABS sealing glass.

\section{Microstructure analysis}

It is common sense to study the structure of material with regard to their function. The transforms of macroscopic properties of materials are created by the transforms of its microstructure.

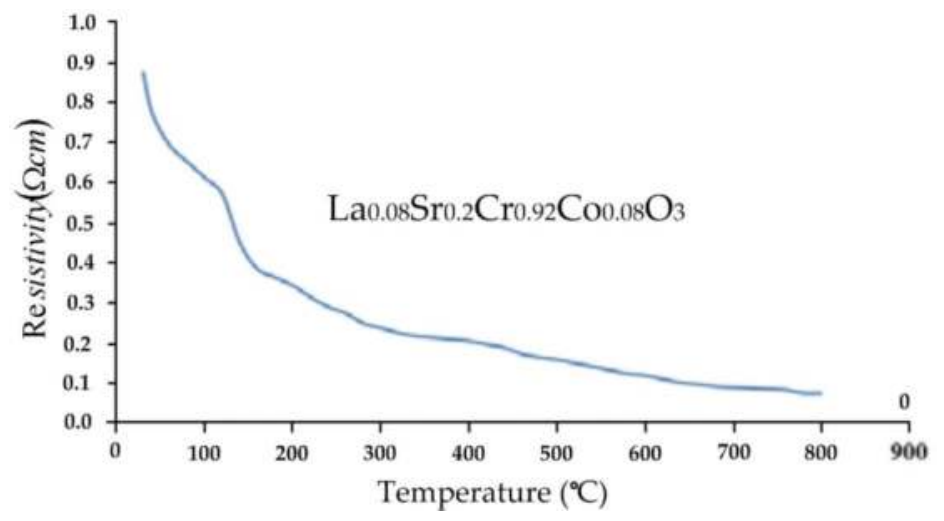

Figure 8. Electrical conductivity of the interconnect $\left(\mathrm{La}_{0.08} \mathrm{Sr}_{0.20} \mathrm{Cr}_{0.92} \mathrm{Co}_{0.08} \mathrm{O}_{3}\right)$ composite at different temperatures [9].
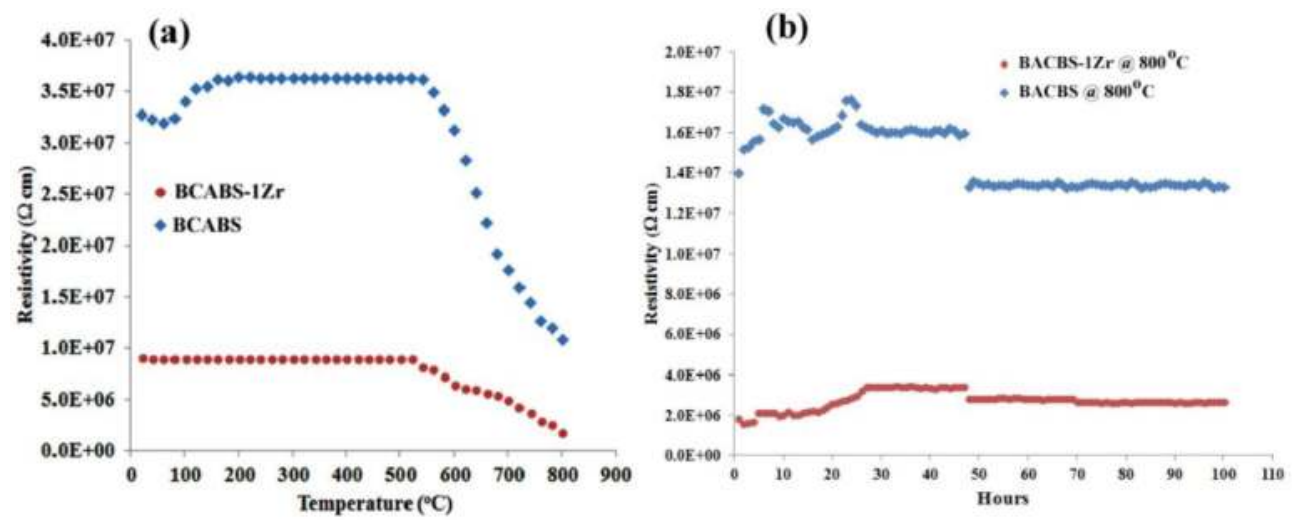

Figure 9. (a) Electrical stability of $\mathrm{BCABS}$ and $\mathrm{BCABS}-1 \mathrm{ZrO}_{2}$ sealing glass at different temperatures; (b) the electrical stability of refractory sealing glass $\mathrm{BCABS}$ and $\mathrm{BCABS}-1 \mathrm{ZrO}_{2}$ at $800^{\circ} \mathrm{C}$ for $100 \mathrm{~h}$ [9]. 


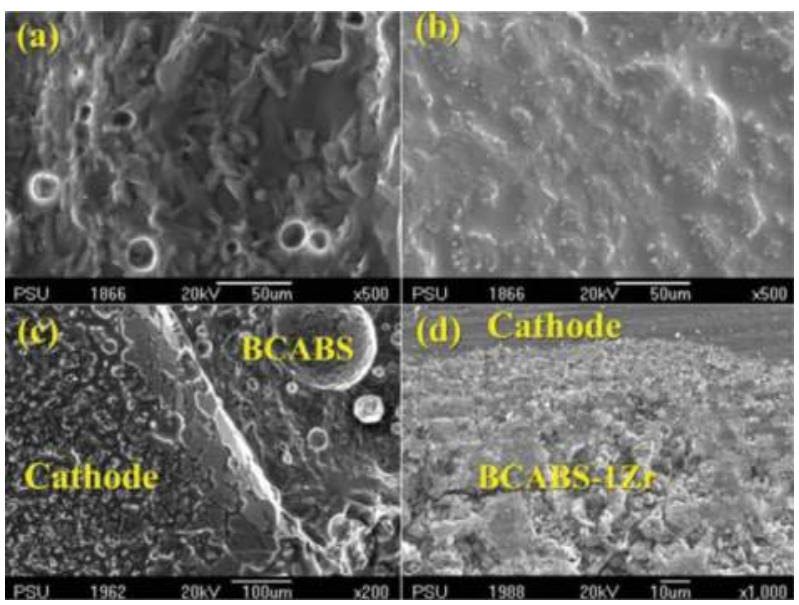

Figure 10. Microstructure of refractory glass: (a) BCABS; (b) $\mathrm{BCABS}-1 \mathrm{ZrO}_{2}$ on the cathode surface. Microstructure of the cross-section between cathode materials and glass: (c) BCABS sealing glass; (d) $\mathrm{BCABS}-1 \mathrm{ZrO}_{2}$ sealing glass [9].

For example, porosity, density, grain, and so forth. On the contrary, a highly compact structure or higher density at the surface of the materials can cause slower moisture migration during hot drying or water penetration into the interior during rehydration [21]. In particular images investigating technologies and structures, reconstruction methods have been presented as powerful and reliable tools in fuel cell and component research. The microstructure can allow analysis of the coating of barium aluminosilicate on the fuel cell that is the main problem of $\mathrm{BCABS}$ glass when used with the cathode based on the barium oxide $(\mathrm{BaO})$. Figure 10 (a) reveals the microstructure of refractory glass BCABS with a rough surface free of cracks. Due to both the sealing glass and fuel cell containing barium oxide, they are sintered together as this can combine the phase of barium oxide composition coated on the surface of the fuel cell. Figure 10(b) presents the microstructure of refractory glass $\mathrm{BCABS}-1 \mathrm{ZrO} \mathrm{r}_{2}$ with a smooth surface free of cracks and blisters, which may be generated from the addition of $\mathrm{ZrO}_{2}$. Figure 10(c) shows the microstructure of refractory glass BCABS on a cross-section between glass and cathode, which indicates the formation of barium aluminosilicate and no occurrence of cracks. Figure 10(d) reveals the microstructure of refractory glass $\mathrm{BCABS}-1 \mathrm{ZrO} \mathrm{r}_{2}$ on the cross-section between glass and cathode, which indicates excellent contact without the formation of barium aluminosilicate or cracks [9].

\section{Conclusion}

The BCABS sealing glass is easily mixed with the cathode side (containing barium oxide, particularly BSCF and BYCF) of SOFCs at high temperatures. The cathode side of SOFCs receives $\mathrm{O}_{2}$ or air for generating electricity to the external circuit. The cathode is conducted by BCABS sealing glass that can clearly reduce the power density in SOFCs. An improved glass ceramic sealant containing the addition of $0.4 \mathrm{~mol} \% \mathrm{ZrO}_{2}$ in the BCABS glass composition was developed. The addition of $\mathrm{ZrO}_{2}$ in the sealing glass can prevent the spreading of barium 
aluminosilicate on the surface of the SOFCs. The melting point of the mixture is $867.25^{\circ} \mathrm{C}$. The electrical resistivity of this mixture is $4 \mathrm{M} \Omega$ which is 8 times lower than BCABS, but is very useful for preventing leaks and did not disturb the electricity of the fuel cell. The thermal expansion coefficient reveals a value of $12.40 \times 10^{-6} /{ }^{\circ} \mathrm{C}$, which is close to that of the $\mathrm{GDC}_{10}$ electrolyte which can protect against the breaking of the cell. The microstructure surface of the mixture exhibits no cracks and is shiny. Therefore, addition of $0.4 \mathrm{~mol} \% \mathrm{ZrO}_{2}$ to $\mathrm{BCABS}$ can be promoted as a useful sealing technology for SOFCs which contain barium oxide.

\section{Author details}

Montri Suklueng

Address all correspondence to: montri.su@psu.ac.th

Energy Systems Research Institute (PERIN), Prince of Songkla University, Songkhla, Thailand

\section{References}

[1] Brett DJ, Atkinson A, Brandon NP, Skinner SJ. Intermediate temperature solid oxide fuel cells. Chemical Society Reviews. 2008;37:1568-1578

[2] Mahapatra M, Lu K. Seal glass for solid oxide fuel cells. Journal of Power Sources. 2015; 195:7129-7139

[3] Singh RN. Innovative Self Healing Seals for Solid Oxide Fuel Cells (SOFC). DOE Award DE-09FE001390: University of Cincinnati; 2012

[4] Piao J, Sun K, Zhang N, Chen X, Zhou D. Sealing glass of barium-calcium-aluminosilicate system for solid oxide fuel cells. Journal of Rare Earths. 2007;25:434-438

[5] Liu QL, Khor KA, Chan SH. High-performance low-temperature solid oxide fuel cell with novel BSCF cathode. Journal of Power Sources. 2006;161:123-128

[6] Suklung M, Yoong VN, Peter H, Ming LC. Optimization of a novel composite cathode for intermediate temperature SOFCs applications. Walailak Journal of Science and Technology (WJST). 2014;12:373-381

[7] Fergus JW. Sealants for solid oxide fuel cells. Journal of Power Sources. 2005;147:46-57

[8] Ghosh S, Kundu P, Sharma AD, Basu RN, Maiti HS. Microstructure and property evaluation of barium aluminosilicate glass-ceramic sealant for anode-supported solid oxide fuel cell. Journal of the European Ceramic Society. 2008;28:69-76

[9] Suklueng M, Voo NY, Lim CM, Razak H, Hing P. The effect of $\mathrm{ZrO}_{2}$ on the structure of barium calcium aluminium boro-silicate (BCABS) glass. Journal of The Australian Ceramic Society Volume. 2015;51:63-68 
[10] Becker PF. Transient thermal stress behavior in $\mathrm{ZrO}_{2}$-toughened $\mathrm{Al}_{2} \mathrm{O}_{3}$. Journal of the American Ceramic Society. 1981;64:37-39

[11] Liang B, Ding C. Thermal shock resistances of nanostructured and conventional zirconia coatings deposited by atmospheric plasma spraying. Surface and Coatings Technology. 2005;197:185-192

[12] Lyskov N, Kolchina L, Galin M, Mazo G. Optimization of composite cathode based on praseodymium cuprate for intermediate-temperature solid oxide fuel cells. Russian Journal of Electrochemistry. 2015;51:450-457

[13] Ananthanarayanan A, Kothiyal GP, Montagne L, Tricot G, Revel B. The effect of $\mathrm{P}_{2} \mathrm{O}_{5}$ on the structure, sintering and sealing properties of barium calcium aluminum boro-silicate (BCABS) glasse. Materials Chemistry and Physics. 2011;130:880-889

[14] Habibi M, Yang S, Guo S. Phase stability and hot corrosion behavior of $\mathrm{ZrO}_{2}-\mathrm{Ta}_{2} \mathrm{O}_{5}$ compound in $\mathrm{Na}_{2} \mathrm{SO}_{4}-\mathrm{V}_{2} \mathrm{O}_{5}$ mixtures at elevated temperatures. Ceramics International. 2014;40:4077-4083

[15] Pavlyuchkov D, Savinykh G, Fabrichnaya O. Experimental investigation and thermodynamic modeling of the $\mathrm{ZrO}_{2}-\mathrm{MgO}-\mathrm{Al}_{2} \mathrm{O}_{3}$ system. Journal of the European Ceramic Society. 2014;34:1397-1408

[16] Villanova J, Sicardy O, Fortunier R, Micha J-S, Bleuet P. Determination of global and local residual stresses in SOFC by X-ray diffraction. Nuclear Instruments and Methods in Physics Research Section B: Beam Interactions with Materials and Atoms. 2010;268:282-286

[17] Liu M, Lynch ME, Blinn K, Alamgir FM, Choi Y. Rational SOFC material design: New advances and tools. Materials Today. 2011;14:534-546

[18] Tietz F. Thermal expansion of SOFC materials. Ionics. 1999;5:129-139

[19] Guo T, Zhang L, Song X, Dong X, Shirolkar MM, Wang M, Li M, Wang H. Influences of $\mathrm{Gd}_{2} \mathrm{Ti}_{2} \mathrm{O}_{7}$ sintering aid on the densification, ionic conductivity and thermal expansion of $\mathrm{Gd}_{0.1} \mathrm{Ce}_{0.9} \mathrm{O}_{1.95}$ electrolyte for solid oxide fuel cells. Journal of Power Sources. 2014;262: 239-244

[20] Acchar W, Sousa C, Mello-Castanho S. Mechanical performance of $\mathrm{LaCrO}_{3}$ doped with strontium and cobalt for SOFC interconnect. Materials Science and Engineering A. 2012; 550:76-79

[21] Iwai H, Shikazono N, Matsui T, Teshima H, Kishimoto M, Kishida R, Hayashi D, Matsuzaki K, Kanno D, Saito M, Muroyama H, Eguchi K, Kasagi N, Yoshida H. Quantification of SOFC anode microstructure based on dual beam FIB-SEM technique. Journal of Power Sources. 2010;195:955-961 